\title{
Ecosystem-Based on Bibilo Fishery Management as a Sustainability Strategy at Limboto Lake
}

\author{
Hasim $^{1}$, Muh. Firyal Akbar ${ }^{2}$ \\ $\left\{\right.$ hasim@ung.ac.id $\left.{ }^{1}\right\}$ \\ Universitas Negeri Gorontalo ${ }^{1}$ \\ Universitas Muhammadiyah Gorontalo ${ }^{2}$
}

\begin{abstract}
The last few decades, Limboto Lake has been degraded as indicated by the rapid growth of aquatic plant populations and higher sedimentation. The area of aquatic plants is estimated at $25 \%$ of the total lake area, which is 3000 ha. Meanwhile, the average lake depth is 3 meters in 2017, while in 1930, it is 25 meters. This study aims to examine the Bibilo fishery profile and review the development model based on the ecosystem approach. The study was conducted in cross-sectional, observational and descriptively analyzation. The respondent determination was carried out in an accidental manner towards Bibilo fishermen. The results showed that Bibilo fishermen were classified as low socio-economic. While Bibilo fishery is the main livelihood in their economic activities. The literature study provides information that Bibilo fishery has the potential to become phytoremediation to contaminate the quality of lake water. Thus, it has the potential to be developed as an ecosystem-based fishery management model.
\end{abstract}

Keywords: ecosystem approach, bibilo fishery, limboto lake

\section{Introduction}

Natural resources on lake are a strategic resource for development. Because lakes contain important resources that can be recovered and resources that could not. Some of the lake's strategic functions are presented by Gownaris et al. [1] and Joniak et al. [2], stated as ecosystems which store natural resources and reservoirs, sources of clean water, and tourist destinations. Therefore Sullivan \& Reynolds [3], explained that the role of lakes for life is far greater when compared to its area.

The central government identifies 15 national critical lakes, one of them is Limboto. This lake is the largest lake in Gorontalo Province and has inlet river and 23 tributaries. The position of Limboto is topographically located in the lowlands surrounded by hills at elevation 
of 20 meters above the sea. Based on a literature review illustrated that there has been massive degradation in Limboto. This is indicated by the growth of massive water plants and high sedimentation. Hasim stated that in 2030, Limboto will be covered by water plants if no appropriate management measures are taken. Based on the GIS analysis in Limboto, the marginal corresponding waters for the Floating Net Cage (KJA) system were 8.03 ha $(0.36 \%)$, while the rest were not suitable for covering an area of 2.195 .57 ha (99.64\%) [4]. These data reinforce the argument that degradation seriously occurred in Limboto. Then, it will be impacted on three aspects (1) the ecological function of the lake as a natural reservoir and the balance of the geohydrological cycle will be threatened; (2) the socio-economic function of the people who have high economic dependence on lake will have a major impact, Hasim \& Mopangga [5], stated that the total value Limboto fisheries is IDR. 51,474,000,000. One of the fisheries economies that exist today is Bibilo fishery; (3) the extinction of lake ecosystem biodiversity resources as wealth that cannot be substituted with money.

One of the economic activities that have contributed to the siltation of Limboto is Bibilo fishery [6]. Bibilo fishery is a fishery activity that utilize the riparian lake by knitting and compacting and then placed in certain water. It aims to attract fish's life under the Bibilo. Functionally, Bibilo fishery is the same as clumps in capture fisheries. According to the field research, the information was obtained that Bibilo fishery had been there since around 1970 . Thus, the Bibilo fishery activity had become a cultural part of the Limboto lake fishing community. Cause it is not merely an economic activity but also a cultural activity that is as a human response in interacting with its natural environment.

In another hand, the Gorontalo government has made a policy regarding the ban on Bibilo fishery in Limboto. At this level, there are two different points of view, (1) Bibilo fishery are negative because they contribute to sedimentation, (2) by considering the weak aspects of vertical mobility of Bibilo fishermen, the prohibition without a solution becomes unwise. Many studies related to Limboto have been carried out such as Sumano and Sukamto [7] related to nitrate content, Suryandari and Sugianti [8], related to water plants, Hasim et al., [5], suitability of KJA fisheries systems. There are no studies related to Bibilo fishery in their social, economic and ecological perspectives. Therefore, this study aims to examine (1) the profile of the Limboto fisheries, (2) Bibilo fishery in the ecosystem approach. It is expected 
that research output will become scientific information in formulating integrated and lake environmentally friendly management policies.

\section{Methodology}

The place of the research was carried out in the Limboto area and cross-sectionally. Data collection was carried out at one point in time, thus generally describing the conditions during the activity. The study was conducted by the observational method and in-depth interviews with respondents which is Bibilo fishermen. Determination of respondents was carried out accidentally by finding fishermen in the field and then descriptive analysis was carried out.

\section{Result and Discussion}

\subsection{Characteristics of Bibilo Fishermen}

The results of data collection illustrated most respondents in the productive age category, ranging from $32-60$ years. And only $10 \%$ are above the productive age (65 years). This data provides an interpretation that one of the strengths of Bibilo fishermen from the HR aspect of fishermen is to be very productive. One side of the Bibilo fishery economy does not require high skills. This is indicated by most respondents having an elementary education level or not graduating (90\%) while $10 \%$ having a high school education. Thus, the Bibilo fishery economy is the last choice for fishermen. The ability of vertical mobility is very low. The implication of Limboto degradation will seriously effect on Bibilo fishermen whose alternative employment options are very limited.

The characteristic on economic aspects are various based on the choice of Bibilo fishery production facilities, that is the Bibilo fishery area. Based on the observation, every day the harvest of Bibilo fishermen ranges from 3-30 kg/day with a selling value of IDR. 25,000/kg. Thus, if the fishing activities are carried out for 25 days/month, the value of the income ranges from IDR. 1,875,000 - IDR. 18,750,000/month. If associated with the number of household members covered is a majority of $>4$, generally Bibilo fishermen are in the poorer group.

\subsection{Bibilo fishery System}

According to Law No. 45, 2009 concerning Amendments to Law No. 31, 2004 concerning Fishery, fishery is all activities related to the management and utilization of fish resources and 
their environment ranging from pre-production, production, processing to marketing carried out in a system fishery business. The definition provides two main keywords. These are management and utilization. Management is related to the sustainability aspects of natural resources and their ecosystems. While utilization is related to the use of directly and indirectly to obtain economic value.

Bibilo fishery is an activity of utilizing fish resources through Bibilo techniques which are used as FADs for gathering fish. Based on the observation, Bibilo was originally inspired by discovering various fishes which gathered in and after water plants. Then the water plants in the profundal mint were transferred to the central part of the lake's water by compressing them. The Information from the initial field of Bibilo fishermen was in the Limehe village then developed throughout the coastal area of Limboto.

Field observation provides information that Bibilo activity is the development of pantango, a tool for collecting fish using coconut leaves. This tool is an adaptation of FADs used in the sea. Then it developed into a Bibilo which was having more high productivity. Based on the functions and materials used, Bibilo can be interpreted as a capture fishery made from various types of aquatic plants formed by rectangles placed floating in the waters of the lake in order to collect fish. Whereas Bibilo fishermen are fishermen who use Bibilo as their capture fishery facility. The Bibilo does not be carried away, then the sides are mounted on a step and ballast. According to Lamangantjo [6], the process of making Bibilo has two kinds, namely; (1) naturally, during the dry season the electoral part of the littoral tree will grow with various fertile plants. During the rainy season, this area will be flooded with water so that the water plants rise above the surface. The plants are then compacted by combining them into Bibilo; (2) artificially, the people plant the plants themselves and harvest them during the rainy season.

Based on the information, the initial field of Bibilo was made only for the needs of fishermen themselves in increasing their catch. But now it has developed as one of the parttime jobs for sale. The price is depending on the size and type of plants used. Bibilo, which uses plants with a long-lasting level and has root parsing near the base, the price is relatively expensive, which can reach one million, while the cheapest is IDR. 750,000.

Generally, Bibilo has a size of $5 \times 50$ or $250 \mathrm{~m} 2$ and it is placed at a minimum depth of 1.5 meters. The types of plants used as Bibilo include water hyacinth, water spinach, water 
grass. The fish collected and harvested are various, namely carp, tilapia fish, tilapia, cork fish and Dawes. Based on the information from Bibilo fishermen, the harvest was carried out in two ways: large harvests and daily harvests. Large harvests are carried out every 6 months or once a year, while daily harvests are carried out on a day to day fishing basis. The productive age of Bibilo is 1-3 years more, and if Bibilo is unproductive it will sink or be drowned. Biblio's unproductive indicators are based on consideration of the productivity of the fish caught. The decline in fish caught under Bibilo waters, because Bibilo has begun to break down so it is no longer comfortable as a place to live fish and forage.

\subsection{The Ecosystem Approach on Bibilo Fishery Management}

Odum [9] and Payne [10], show that ecosystems have two main components namely biotic and abiotic. these components interact in two main functions in the ecosystem, namely the material cycle and energy flow. The running of this function will determine the carrying capacity and environmental services of the ecosystem. Conversely, disturbances to the constituent components of the ecosystem will have an impact on the ecological functions of the ecosystem.

The main economic activity in Limboto is KJA system aquaculture which has energy inputs in the form of very high pellet feed. Some literature provides information that the feed given is $5 \%$ of the weight of the fish that is maintained. Thus, the cultivation activities provide two impacts; (1) waste of fish metabolism and (2) waste food that is not consumed. Some literature provides information that is about $20 \%$ of food that is not consumed by fish, goes directly into the environment into the water system. As Johansson et al. [11] stated, aquaculture in lakes has an impact on ecosystems, for example in the form of phosphate organic matter, ammonia, and sedimentary particles. While Bechman et al. [12] [13], provide a report on the results of research that agricultural activities have an impact on eutrophication in lakes. Organic matter which is high content in Limboto lake should be controlled in an integrated manner through the ecosystem approach on Bibilo fishery management. It is because one of the advantages of water plants used these organic ingredients as nutrients for their growth. Thus, the content of organic matter in the waters will decrease.

Field observations provide information about several reasons conveyed by the public about their view that Bibilo contributed to silting the lake;(1) when the Bibilo is full-use, it can settle the bottom-lake and it becomes part of the sedimentary material; (2) Bioproducts of certain 
plant types which are classified as rapid, such as water hyacinth, give rise to floating islands and increase evapotranspiration; (3) Ballast used by some Bibilo fishermen namely landfilled in sacks; (4) There are certain types of plants whose roots reach the bottom that they can accelerate siltation.

Some of the development of ecosystem-based Bibilo fishery management are as follows: (1) The types of plants used are simplified using certain wild plants in the waters of the lake. For example, Eichhornia crassipes, Salvinia cucullata, Enydra sp, and kale. This water plant becomes biofilter and it could have ecological function. Some studies provide information on the positive aquatic plants role that can reduce chemical pollution and soil particles. This means that Bibilo has a positive role in the context of controlling lake water quality, compared to floating net aquaculture. In this context there is local wisdom on Bibilo fishery in Limboto Lake. (2) Replace the use of ballast from the sand with mountain stones inserted in the sack, so Bibilo weights can still be used even it is full; (3) The amount is limited to avoiding dioxygenase at night because it is harmful to aquatic biota especially fish; (4) Placement is arranged, for example, integrating with domestic or other sources of pollution points to maximize the function of biofilter from plants; (5) Monitoring plant density regularly, to control its area; (6) The unproductive Bibilo is not drowned otherwise it is lifted ashore and made into compost. Bibilo fishery development in the ecosystem approach emphasizes output management. The ecological, social and economic impacts that will occur in the Limboto ecosystem can be minimized.

\section{Conclusion}

The Fishermen of Bibilo fishery in Limboto are in the weak socio-economic group. These conditions affect the limitation ability of vertical. The prohibition of Bibilo fishery has become unwise and there is not solution from the government. The Bibilo fishery system is culture because it is an effort by fishermen communities to survive in their lives and at the same time respond to environmental use. The Bibilo fishery system can be developed based on an ecosystem approach and these activities have more environmentally friendly aspects. Management of ecosystem-based Bibilo fishery systems must be carried out in an integrated manner in the Limboto lake management system. 


\section{References}

[1] N.J. Gownaris, K.J. Rountos, L. Kauman, J. Kolding, , K.M.M. Lawiza, E.K. Pikitch, "Water level fluctuations and the ecosystem functioning of lakes," Journal of Great Lakes Research, 44, pp. 1154-1163, 2018.

[2] T. Joniak, N. Jakubowska, E.S. Wasielewska, "Degradation Of The Recreational Functions Of Urban Lake: A Preliminary Evaluation Of Water Turbidity And Light Availability (Strzeszyńskie Lake, Western Poland)," Polish Journal Of Natural Sciences, Abbrev: Pol. J. Natur. Sc., Vol. 28(1): 43-51, 2013

[3] P.E. Sullivan, C.S. Reynolds, "Limnology and Limnetic Ecology," USA: Blackwell Publishing, 2003.

[4] Hasim, H. Mopangga, "Valuation the Fishery Economic Value Limboto Lake Gorontalo," Haya: The Saudi Journal of Life Sciences (SJLS), Vol-3, Iss-5, 443-446, May, 2018.

[5] Hasim, Y. Koniyo, F. Kasim, "Suitable location map of floating net cage for environmentally friendly fish farming development with Geographic Information Systems applications in Lake Limboto, Gorontalo, Indonesia," AACL Bioflux, Vol. 10, Issue 2, 2017.

[6] C. Lamangantjo, "Bibilo dan Pengaruhnya Terhadap Eksositem Danau Limboto," Skripsi FKIP, Universitas Sam Ratulangi di Gorontalo, 1992.

[7] D. Sumarno, Sukamto, "Analisis Kandungan N-Nitrat Dan Orthofosfat Di Bibilo Dan Daerah Bebas Danau Limboto, Provinsi Gorontalo," Buletin Teknik Litkayasa Sumber Daya Dan Penangkapan; Vol 8 (2), p. 73-77, 2010.

[8] Suryandari, Astri, Y. Sugianti, "Tumbuhan air di danau limboto, gorontalo: manfaat dan permasalahannya," Jurnal Bawal, 2 (4) pp.151-154, 2009.

[9] E.P. Odum, "Dasar-Dasar Ekologi," Gadjah Mada University Press, 1996.

[10] A. Payne, "The Ecology Tropical Lake and Rivers," Jhon Willey \& Sons, New York, 1986.

[11] T. Johanson, L. Hakanson, K. Borum, J. Persson, "Direct Flows of Phophorous and Suspended Metter Form a Fish Farm to Wild Fish in Lake Southren Bollarean, Sweden," Aquacultue Engineering, 17, pp.111-137, 1998. 
[12] M.E. Bechman, D. Berge, H.O. Eggestad, S.M. Vansemb, "Phosphorus transfer from agricultural areas and its impact on the eutrophication of lakes-two long-term integrated studies from Norway," Journal of Hydrology 304, pp. 238-250, 2004.

[13] W. R. Ginanjar and A. Z. Mubarrok, "Civil Society and Global Governance: The Indirect Participation of Extinction Rebellion in Global Governance on Climate Change," J. Contemp. Gov. Public Policy, vol. 1, no. 1, pp. 41-52, 2020. 